\title{
ANALISIS LAPORAN KEUANGAN UNTUK MENILAI KINERJA PT. MULTI SUKSES MAKMUR PERKASA
}

\author{
Markus Muda, SE \\ Jurusan Akuntansi Keuangan Publik \\ Program Studi Diploma IV Akuntansi \\ Politeknik Katolik Saint Paul Sorong \\ Email : markusmuda@gmail.com
}

\begin{abstract}
Abstrak
Laporan keuangan merupakan alat yang sangat penting dalam memperoleh informasi sehubungan dengan kondisi keuangan dan hasil-hasil yang dicapai oleh perusahaan. Penelitian ini bertujuan untuk menganalisis laporan keuangan dengan tujuan untuk mengetahui tingkat likuiditas dan profitabilitas sebagai hasil kinerja perusahaan yang berguna bagi bahan pertimbangan manajemen perusahaan maupun bagi pihak diluar perusahaan. Hasil dari penelitian ini adalah adanya penurunan rasio baik likuiditas maupun profitabilitas pada tahun 2014, namun penurunan ini tidak berarti perusahaan tidak likuid sebab perusahaan masih dapat membayar hutang-hutangnya dengan baik.
\end{abstract}

Kata Kunci : Laporan Keuangan, kinerja, likuiditas, dan profitabilitas

\begin{abstract}
The financial report is a very important tool in obtaining information with respect to the financial condition and results achieved by the company. This study aimed to analyze the financial statements in order to determine the level of liquidity and profitability as a result of the performance of companies that are useful for consideration for the management of the company as well as outside the company. Result of this study was a decrease in both liquidity and profitability ratios in 2014, but this decline does not mean the company is not liquid because the company is still able to pay its debts well.
\end{abstract}

Keywords: Financial Statement, performance, liquidity, and profitability

\section{PENDAhULUAN}

\section{Latar Belakang}

PT.Multi Sukses Makmur Perkasa merupakan perusahaan yang bergerak dibidang usaha dagang. Keuntungan merupakan persyaratan kelangsungan hidup bagi perusahaan. Diperlukan ukuran-ukuran atau indikator-indikator keuangan untuk mengetahui keberhasilan perusahaan dalam upaya mencapai tujuannya yaitu untuk menghasilkan keuntungan tersebut, apakah hasil tersebut sudah dapat dikatakan maksimal atau belum biasanya diukur dengan menggunakan angka-angka tertentu. Indikatorindikator tersebut dapat diperoleh dari laporan keuangan yang disusun secara periodik, yang secara umum berupa laporan neraca dan rugilaba. Untuk mengetahui indikator-indikator keuangan tersebut dilakukan dengan analisis laporan keuangan.

Dalam melakukan analisis terhadap laporan keuangan digunakan metode dan teknik analisis untuk menentukan dan mengukur hubungan antara pos-pos dalam laporan keuangan, sehingga diketahui perubahan masing-masing pos bila diperbandingkan. Hasil dari perbandingan tersebut dapat digunakan untuk mengetahui tingkat likuiditas dan profitabilitas yang dapat menggambarkan kondisi keuangan dan kinerja perusahaan. Selama ini, PT.Multi Sukses Makmur Perkasa tidak pernah menggunakan rasio untuk menilai kinerja maupun profitabilitas usahanya, maka dalam penulisan Tugas Akhir ini penulis akan mencoba menganalisis laporan keuangan yang berupa: Laporan Posisi Keuangan dan Laporan Rugi-Laba. Dengan laporan keuangan tersebut, penulis dapat mengetahui tingkat likuiditas dan profitabilitas. Dalam penulisan Tugas Akhir ini, penulis tertarik untuk mengambil judul: "Analisis Laporan Keuangan untuk Menilai kinerja PT.Multi Sukses Makmur Perkasa”.

\section{Rumusan Masalah}

Berdasarkan latar belakang masalah, maka masalah-masalah yang akan menjadi pokok pembahasan pada penelitian ini adalah: "Berapa besar tingkat likuiditas dan profitabilitas serta 
perubahannya dilihat dari laporan keuangan yang disajikan PT.Multi Sukses Makmur Perkasa untuk periode 2013 dan 2014.

\section{Tujuan Penelitian}

Tujuan merupakan target atau sasaran yang ingin dicapai dalam melakukan suatu kegiatan. Tujuan dari penelitian ini adalah Untuk mengetahui besarnya tingkat likuiditas dan profitabilitas dilihat dari laporan keuangan yang disajikan PT.Multi Sukses Makmur Perkasa untuk periode 2013 dan 2014.

\section{TINJAUAN PUSTAKA}

Kinerja keuangan merupakan pencapaian prestasi perusahaan pada suatu periode yang menggambarkan kondisi kesehatan keuangan perusahaan dengan indikator kecukupan modal, likuiditas dan profitabilitas. Laporan keuangan adalah hasil dari proses akuntansi yang disebut siklus akuntansi. Laporan keuangan menunjukkan posisi sumber daya yang dimiliki oleh perusahaan selama satu periode. Selain itu, laporan keuangan juga menunjukkan kinerja keuangan perusahaan yang ditunjukkan dengan kemampuan perusahaan dalam menghasilkan pendapatan dengan sumber daya yang dimiliki oleh perusahaan. Pemakai laporan keuangan meliputi investor, karyawan, pemberi pinjaman, pemasok dan kreditor usaha lainnya, pelanggan, pemerintah serta lembaga-lembaga masyarakat (Darsono; 2004).

Laporan posisi keuangan adalah laporan tentang posisi keuangan perusahaan pada tanggal tertentu seperti yang tertera dalam laporan. Jadi, kondisi yang dijelaskan dalam laporan posisi keuangan adalah kondisi pada tanggal tertentu. Biasanya Laporan Posisi Keuangan dibuat per 31 Desember, atau tiap akhir bulan.

Laporan Laba Rugi merupakan akumulasi aktivitas yang berkaitan dengan pendapatan dan biaya selama periode waktu tertentu, misalnya bulanan atau tahunan. Untuk melihat periode waktu yang dilaporkan, maka pembaca laporan laba rugi perlu memperhatikan kepala pada laporan tersebut. Komponen laporan laba rugi adalah pendapatan/penjualan, Harga pokok penjualan, biaya pemasaran, biaya administrasi dan umum, pendapatan luar usaha, biaya luar usaha.
Analisis laporan keuangan adalah aplikasi dari alat dan teknik analitis untuk laporan keuangan bertujuan umum dan data-data yang berkaitan untuk menghasilkan estimasi dan kesimpulan yang bermanfaat dalam analisa bisnis (Subramanyam; 2012).

Rasio likuiditas yaitu rasio-rasio yang digunakan untuk mengukur kemampuan perusahaan untuk memenuhi kewajiban finansial jangka pendeknya atau kewajiban yang harus segera dipenuhi. Jika perusahaan mampu memenuhi kewajiban keuangan tepat pada waktunya maka perusahaan tersebut dalam keadaan likuid, sebaliknya jika perusahaan tidak dapat memenuhi kewajiban keuangan jangka pendeknya, berarti perusahaan tersebut dalam keadaan ilikuid.

Rasio profitabilitas mengukur laba dan keberhasilan operasi suatu perusahaan dalam suatu periode waktu tertentu. Laba (atau mungkin rugi) mempengaruhi kemampuan perusahaan untuk mendapat pendanaan utang atau ekuitas. Selain itu juga mempengaruhi posisi likuiditas perusahaan dan kemampuan perusahaan untuk berkembang. Oleh karena itu, baik kreditor maupun investor, sangat tertarik untuk mengevaluasi kemampuan perusahaan memperoleh laba atau profitabilitas.

\section{METODE PENELITIAN}

\section{Teknik dan Metode Pengumpulan Data}

Data-data yang dipergunakan dalam penelitian ini adalah data Primer, yaitu data yang diperoleh secara langsung dari lokasi objek penelitian meliputi sejarah berdirinya perusahaan, struktur organisasi dan lain-lain. Data Sekunder, yaitu data yang diberikan oleh pihak perusahaan yang berupa laporan neraca dan laba rugi.

Teknik analisis data yang digunakan adalah deskriptif kuantitatif persentase. Deskriptif merupakan tulisan yang berisi paparan uraian tentang suatu objek sebagaimana adanya pada waktu tertentu. Kuantitatif adalah data yang dapat diolah atau diukur. Jadi metode yang digunakan dalam penelitian ini adalah dengan menggunakan tulisan yang berisi paparan uraian tentang suatu objek sebagaimana seadanya pada waktu tertentu dimana data yang digunakan dapat diolah atau diukur dan hasil dari data yang telah dianalisis tersebut berbentuk persentase. 


\section{Variabel Penelitian}

Variabel dapat didefinisikan sebagai atribut dari seseorang atau obyek yang mempunyai variasi antara satu orang dengan yang lain atau satu obyek dengan obyek yang lain. Variabel independen atau variable bebas dari penelitian ini adalah laporan keuangan PT.Multi Sukses Makmur Perkasa yang akan mempengaruhi kinerja Perusahaan, sedangkan variable dependen atau variable terikat dari penelitian ini adalah kinerja PT.Multi Sukses Makmur Perkasa yang akan dinilai dengan analisis rasio keuangan berupa rasio likuiditas dan rasio profitabilitas.

\section{PEMBAHASAN DAN HASIL}

\section{Penyajian Data}

Penulis melakukan analisis terhadap laporan keuangan perusahaan untuk menghitung rasio likuiditas dan profitabilitas PT.Multi Sukses Makmur Perkasa untuk periode 31 Desember 2013, Desember 2014. Berdasarkan data yang berhasil di kumpulkan maka penulis menganalisis dan menguraikan rasio sebagai berikut :

\section{Rasio Likuiditas}

a. Rasio Lancar

Rasio ini merupakan rasio yang digunakan untuk mengukur kemampuan perusahaan dalam membayar kewajiban jangka pendeknya dengan menggunakan aktiva lancar yang dimiliki.

b. Rasio Cepat

Rasio ini dipakai sebagai ukuran kemampuan perusahaan untuk membayar dengan segera utang lancarnya. Persediaan tidak termasuk didalamnya karena persediaan dianggap memerlukan waktu yang cukup lama untuk dapat direalisasikan menjadi kas.

2. Rasio Profitabilitas

a. Gross Profit Margin ( GPM)

Rasio ini digunakan untuk mengukur keuntungan kotor perusahaan disetiap barang yang dijual oleh perusahaan. b. Net Profit Margin ( NPM)

Rasio ini digunakan untuk menghitung kemampuan perusahaan menghasilkan laba bersih pada tingkat penjualan tertentu

c. Return on Asset ( ROA )

Rasio ini mengukur kemampuan perusahaan menghasilkan laba bersih berdasarkan tingkat aset tertentu.

d. Return on Equity ( ROE )

Rasio ini mengukur kemampuan perusahaan menghasilkan laba bersih berdasarkan modal saham yang dimiliki.

\section{Perhitungan}

Untuk menilai posisi keuangan jangka pendek atau likuiditas perusahaan, berikut penulis menyajikan laporan posisi keuangan PT.Multi Sukses Makmur Perkasa secara komparatif 
Tabel 1.

Laporan Posisi Keuangan PT.MSMP

\begin{tabular}{|c|c|c|c|c|c|c|c|}
\hline \multicolumn{8}{|c|}{$\begin{array}{l}\text { PT.Multi Sukses Makmur Perkasa } \\
\text { Laporan Posisi Keuangan ( diringkas ) } \\
\text { 31 Desember }\end{array}$} \\
\hline & \multirow{2}{*}{\multicolumn{2}{|c|}{2013}} & \multirow{2}{*}{\multicolumn{2}{|c|}{2014}} & \multicolumn{3}{|c|}{$\begin{array}{c}\text { Kenaikan/ Penurunan selama } \\
\text { tahun } 2014\end{array}$} \\
\hline & & & & & & Perubahan & $\%$ \\
\hline \multicolumn{8}{|l|}{ Aktiva } \\
\hline \multicolumn{8}{|l|}{ Aktiva Lancar } \\
\hline Kas dan Bank & $\mathrm{Rp}$ & 345.750 .155 & $\mathrm{Rp}$ & 432.464 .602 & $\mathrm{Rp}$ & 86.714 .447 & $20,05 \%$ \\
\hline Persediaan barang & $\mathrm{Rp}$ & 6.429 .547 .852 & $\mathrm{Rp}$ & 9.175 .656 .926 & $\mathrm{Rp}$ & 2.746 .109 .074 & $29,93 \%$ \\
\hline Piutang Dagang & $\mathrm{Rp}$ & - & $\mathrm{Rp}$ & - & $\mathrm{Rp}$ & - & $0,00 \%$ \\
\hline \multirow{2}{*}{$\begin{array}{l}\text { Pajak Dibayar dimuka } \\
\text { Total Aktiva Lancar }\end{array}$} & $\mathrm{Rp}$ & - & $\mathrm{Rp}$ & 32.873 .302 & $\mathrm{Rp}$ & 32.873 .302 & $100,00 \%$ \\
\hline & $\mathrm{Rp}$ & 6.775 .298 .007 & $\mathrm{Rp}$ & 9.640 .994 .830 & $\mathrm{Rp}$ & 2.865 .696 .823 & $29,72 \%$ \\
\hline \multicolumn{8}{|l|}{ Aktiva Tetap } \\
\hline Harga Perolehan & $\mathrm{Rp}$ & 1.105 .047 .908 & $\mathrm{Rp}$ & 1.110 .417 .908 & $\mathrm{Rp}$ & 5.370 .000 & $0,48 \%$ \\
\hline \multirow{3}{*}{$\begin{array}{l}\text { Akm. Penyusutan } \\
\text { Total Aktiva Teta } \\
\text { Total Aktiva }\end{array}$} & $\mathrm{Rp}$ & $(613.431 .408)$ & $\mathrm{Rp}$ & $(746.738 .616)$ & $\mathrm{Rp}$ & (133.307.208) & $17,85 \%$ \\
\hline & $\mathrm{Rp}$ & 491.616 .500 & $\mathrm{Rp}$ & 363.679 .292 & $\mathrm{Rp}$ & (127.937.208) & $-35,18 \%$ \\
\hline & $\mathbf{R p}$ & 7.266 .914 .507 & $\mathbf{R p}$ & 10.004 .674 .122 & $\mathrm{Rp}$ & 2.737 .759 .615 & $27,36 \%$ \\
\hline \multicolumn{8}{|l|}{ Kewajiban } \\
\hline Hutang Bank & $\mathrm{Rp}$ & - & $\mathrm{Rp}$ & - & $\mathrm{Rp}$ & - & $0,00 \%$ \\
\hline Hutang Dagang & $\mathrm{Rp}$ & 3.303 .138 .670 & $\mathrm{Rp}$ & 5.348 .840 .405 & $\mathrm{Rp}$ & 2.045 .701 .735 & $38,25 \%$ \\
\hline Hutang Pajak & $\mathrm{Rp}$ & 152.715 .948 & $\mathrm{Rp}$ & 100.297 .357 & $\mathrm{Rp}$ & $(52.418 .591)$ & $-52,26 \%$ \\
\hline \multirow{2}{*}{$\begin{array}{l}\text { Hutang Lain-lain } \\
\text { Total Kewajiban }\end{array}$} & $\mathrm{Rp}$ & - & $\mathrm{Rp}$ & - & $\mathrm{Rp}$ & & $0,00 \%$ \\
\hline & $\mathrm{Rp}$ & 3.455 .854 .618 & $\mathrm{Rp}$ & 5.449 .137 .762 & $\mathrm{Rp}$ & 1.993 .283 .144 & $36,58 \%$ \\
\hline \multicolumn{8}{|l|}{ Modal } \\
\hline Modal Saham & $\mathrm{Rp}$ & 1.000 .000 .000 & $\mathrm{Rp}$ & 1.000 .000 .000 & $\mathrm{Rp}$ & - & $0,00 \%$ \\
\hline Laba ditahan & $\mathrm{Rp}$ & 2.055.098.619 & $\mathrm{Rp}$ & 2.811 .059 .889 & $\mathrm{Rp}$ & 755.961 .270 & $26,89 \%$ \\
\hline \multirow{3}{*}{\begin{tabular}{|l} 
Laba Tahun Berjalan \\
Total Modal \\
Total Kewajiban \& Modal \\
\end{tabular}} & $\mathrm{Rp}$ & 755.961 .270 & $\mathrm{Rp}$ & 744.476 .471 & $\mathrm{Rp}$ & (11.484.799) & $-1,54 \%$ \\
\hline & $\mathrm{Rp}$ & 3.811 .059 .889 & $\mathrm{Rp}$ & 4.555 .536 .360 & $\mathrm{Rp}$ & 744.476 .471 & $16,34 \%$ \\
\hline & $\mathbf{R p}$ & 7.266 .914 .507 & $\mathbf{R p}$ & 10.004 .674 .122 & $\mathrm{Rp}$ & 2.737 .759 .615 & $27,36 \%$ \\
\hline
\end{tabular}

Sumber : PT.Multi Sukses Makmur Perkasa 
Pada tabel 1 menunjukkan analisis komparatif laporan perubahan posisi keuangan PT.Multi Sukses Makmur perkasa dari tahun 2013-2014. Pada aktiva lancar, persediaan barang dagang naik $9,88 \%$ lebih besar dari pada kas dan bank perusahaan hal ini dikarenakan oleh naiknya hutang dagang sebesar $38,25 \%$. Pada sisi pasiva perusahaan menunjukkan kewajiban perusahaan mengalami kenaikan sedangkan modal saham perusahaan tetap dan laba ditahan yang kenaikannya tidak sebanding dengan kenaikan kewajiban perusahaan pada tahun 2014.

Perhitungan rasio lancar PT.Multi Sukses Makmur Perkasa adalah sebagai berikut :

$$
\begin{aligned}
\text { Current Ratio } & =\frac{\text { Aktiva Lancar }}{\text { Kewajiban Lancar }} \\
\text { Current Ratio } 2013= & \frac{\operatorname{Rp} 6.775 .298 .007,-}{\operatorname{Rp} 3.455 .618,-} \\
& =196 \% 100 \% \\
\text { Current Ratio } 2014= & \frac{\operatorname{Rp} 9.640 .994 .830,-}{\operatorname{Rp} 5.449 .137 .762,-} \\
& =177 \%
\end{aligned}
$$

Dari hasil perhitungan rasio lancar yaitu dengan membandingkan aktiva lancar dan kewajiban lancar pada PT.Multi Sukses Makmur Perkasa tahun 2013 menunjukkan hasil current ratio sebesar 196\% hal ini menunjukkan bahwa setiap Rp.1,00 hutang lancar dijamin dengan Rp. 1,96 aktiva lancar.
Perhitungan rasio cepat PT.Multi Sukses Makmur Perkasa adalah sebagai berikut :

Acid Test Ratio $=\frac{\text { Aktiva lancar }- \text { Persediaan }}{\text { Kewajiban lancar }}$

Acid Test Ratio 2013

$=\frac{\operatorname{Rp~6.775.298.007-Rp~6.429.547.852~}}{\operatorname{Rp~3.455.854.618~}} \times 100 \%$

$=10 \%$

Acid Test Ratio 2014

$=\frac{\operatorname{Rp} 945.000-\operatorname{Rp} 540.000}{\operatorname{Rp~} 303.000} \times 100 \%$

$=9 \%$

Dari hasil perhitungan rasio cepat PT.Multi Sukses Makmur Perkasa tahun 2013 menunjukkan hasil sebesar $10 \%$ hal ini menunjukkan bahwa setiap Rp.1,00 hutang lancar dijamin dengan Rp. 0,10 aktiva lancar selain persediaan. Untuk tahun 2014 rasio cepat sebesar 9\% yang berarti bahwa setiap Rp.1,00 hutang lancar dijamin dengan Rp.0,09 aktiva lancar selain persediaan. Rasio cepat pada tahun 2014 mengalami penurunan sebesar Rp.0,01 dari tahun 2013. Profitabilitas perusahaan diukur dari kesuksesan perusahaan dan kemampuan menggunakan aktivanya secara produktif. Berikut akan disajikan Laporan Laba-rugi PT.Multi Sukses Makmur Perkasa tahun 2013-2014 secara komparatif. 
Tabel 2.

Laporan Laba Rugi PT.MSMP

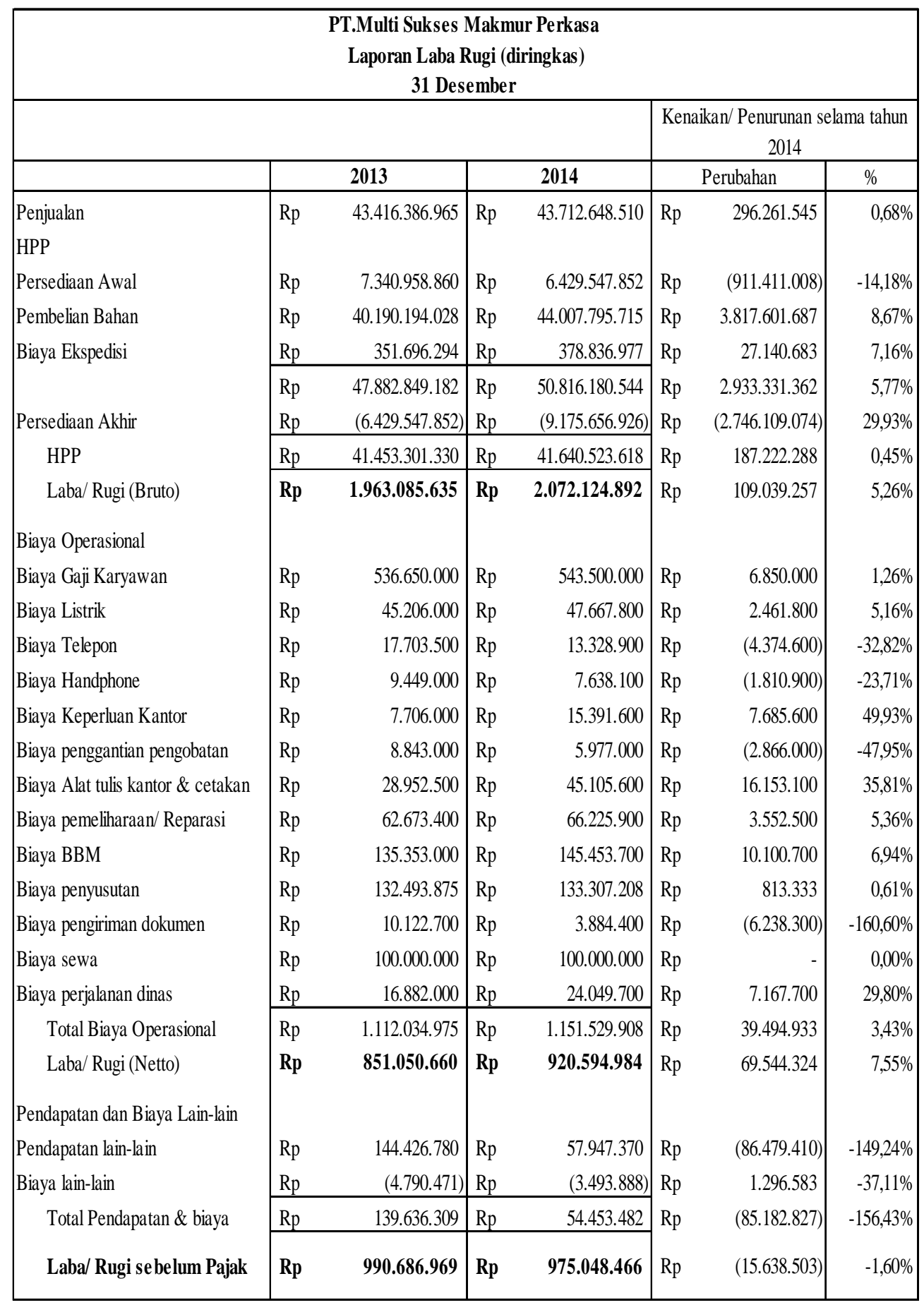

Sumber : PT.Multi Sukses Makmur Perkasa 
Pada tabel 2 menunjukkan analisis komparatif Laba-Rugi PT.Multi Sukses Makmur perkasa dari tahun 2013-2014. Penjualan perusahaan tidak mengalami kenaikan nilai yang signifikan hanya sebesar $0,68 \%$ selain itu biaya operasional naik sebesar $3,43 \%$ dan pendapatan selain penjualan menurun sebesar $149,24 \%$ sehingga perusahaan mengalami penurunan laba pada tahun 2014 sebesar 1,60\%. Rincian perhitungan rasio profitabilitas adalah sebagai berikut :

$$
\mathrm{GPM}=\frac{(\text { Penjualan Bersih }- \text { HPP })}{\text { Penjualan bersih }} \times 100 \%
$$

GPM 2013

$$
\begin{aligned}
& =\frac{(\mathrm{Rp} 43.416 .386 .965-\mathrm{Rp} \mathrm{41.453.301.330)}}{\mathrm{Rp} \mathrm{43.416.386.965}} \times 100 \% \\
& =4,5 \%
\end{aligned}
$$

GPM 2014

$=\frac{(\mathrm{Rp} 43.712 .648 .510-\mathrm{Rp} 41.640 .523 .618)}{\mathrm{Rp} 43.712 .648 .510} \times 100 \%$

$=4,7 \%$

Pada hasil perhitungan diatas margin keuntungan kotor PT.Multi Sukses Makmur Perkasa tahun 2013 sebesar 4,5\% dan naik menjadi $4,7 \%$ pada tahun berikutnya. Kenaikan rasio keuntungan kotor ini menunjukkan bahwa perusahaan mampu menaikkan hasil penjualannya sebesar $0.2 \%$.

$$
\begin{aligned}
\text { NPM } & =\frac{\text { Laba Bersih }}{\text { Penjualan bersih }} \times 100 \% \\
\text { NPM 2013 } & =\frac{R p 990.686 .969}{R p 43.416 .386 .965} \times 100 \% \\
& =2,3 \% \\
\text { NPM 2014 } & =\frac{R p 975.048 .466}{R p 43.712 .648 .510} \times 100 \% \\
& =2,2 \%
\end{aligned}
$$

Net Profit Margin perusahaan menunjukkan hasil sebesar 2,3\% dan pada tahun 2014 menunjukkan hasil sebesar 2,2\%, besar penurunan hasil Net Profit Margin sebesar $0,1 \%$. Ini menunjukkan bahwa perusahaan mengalami penurunan laba bersih dari penjualan barang dikarenakan biaya operasional yang mengalami kenaikan sebesar 3,43\%.

$\mathrm{ROA}=\frac{\text { Laba Bersih }}{\text { Total Aktiva }} \times 100 \%$

$$
\begin{aligned}
\text { ROA } 2013 & =\frac{R p 990.686 .969}{R p 7.266 .914 .507} \times 100 \% \\
& =13,6 \% \\
\text { ROA } 2014 & =\frac{R p 975.048 .466}{R p 10.004 .674 .122} \times 100 \% \\
& =9,7 \%
\end{aligned}
$$

Return on Asset menunjukkan besarnya total aktiva yang digunakan untuk menghasilkan laba bersih. Return on Asset PT.Multi Sukses Makmur Perkasa pada tahun 2014 mengalami penurunan sebesar 3,9\%.

$\mathrm{ROE}=\frac{\text { Laba Bersih }}{\text { Rata-rata Ekuitas }} \times 100 \%$

Rata-rata Ekuitas 2013

$=\frac{(R p 3.560 .059 .800+R p 3.811 .059 .889)}{2}$
$=\operatorname{Rp~} 3.685 .559 .844$

Rata-rata Ekuitas 2014

$=\frac{(R p 3.811 .059 .889+R p 4.555 .536 .360)}{2}$

$=\operatorname{Rp} 4.183 .298 .124$

$$
\begin{aligned}
\text { ROE } 2013 & =\frac{R p 990.686 .969}{R p 3.685 .559 .844} \times 100 \% \\
& =26,9 \% \\
\text { ROE } 2014 & =\frac{R p 975.048 .466}{R p 4.183 .298 .124} \times 100 \% \\
& =23,3 \%
\end{aligned}
$$

Return on Equity pada tahun 2013 sebesar $26.9 \%$ ini berarti setiap Rp.1,00 dari modal sendiri perusahaan dapat mengembalikan keuntungan sebesar 26,9\% atau Rp.0,26. Sedangkan pada tahun 2014 perusahaan dapat mengembalikan keuntungan sebesar 23,3\%.

\section{Kesimpulan dan Saran}

\section{Kesimpulan}

Menurut hasil analisis perbandingan rasio laporan keuangan pada PT.Multi Sukses Makmur Perkasa dapat disimpulkan bahwa :

1. Perusahaan menekankan pentingnya laporan keuangan.

2. Laporan keuangan disusun oleh PT.Multi Sukses Makmur Perkasa sebagai pertanggungjawaban manajemen atas pengelolaan sumber 
daya perusahaan selama satu periode akuntansi dalam hal ini periode dimulai 1 januari dan berakhir 31 desember.

3. Dilihat dari likuiditasnya, perusahaan mampu memenuhi hutang lancarnya walaupun kemampuannya cenderung menurun. Hal ini dapat dilihat dengan adanya penurunan rasio lancar sebesar Rp. 0,19 maupun rasio cepat sebesar Rp. 0,01. Penurunan ini diakibatkan oleh naiknya persentase kewajiban lancar diikuti oleh kenaikan aktiva lancar yang tidak sebanding.

4. Dilihat dari profitabilitasnya, perusahaan dapat menghasilkan laba walaupun pada tahun 2014 mengalami penurunan keuntungan sebesar $1,60 \%$, hal ini dikarenakan adanya kenaikan biaya operasional sebesar 3,43\% tanpa diikuti kenaikan hasil penjualan barang dagang perusahaan yang hanya naik sebesar $0,68 \%$.

\section{Saran}

Untuk menunjang kelancaran dan kesuksesan PT.Multi Sukses Makmur Perkasa, maka saran yang dapat penulis sampaikan adalah sebagai berikut :

1. Perusahaan baiknya membuat laporan keuangan secara lengkap mulai dari Laporan posisi Keuangan, Laporan Laba-Rugi, Laporan Arus Kas, Perubahan Ekuitas, serta dilengkapi dengan catatan atas Laporan Keuangan.

2. Laporan keuangan yang telah disusun harusnya dapat dipertanggung jawabkan pada rapat evaluasi para pemegang saham atau rapat direksi.

3. Perusahaan harus bisa menaikkan tingkat likuiditasnya dari tahun ke tahun. Tingkat likuiditas yang baik adalah 2:1 dimana aktiva lancar yang digunakan untuk membiayai hutang diusahakan lebih besar dari hutang lancarnya.
4. Perusahaan sebaiknya dapat meningkatkan penjualannya dan menekan biaya-biaya yang dikeluarkan oleh perusahaan, sehingga dapat meningkatkan laba perusahaan dari tahun ke tahun. Untuk menekan biayabiaya yang dikeluarkan, perusahaan harus mengadakan evaluasi kinerja perusahaan secara berkala atau setiap akhir tahun periode dalam hal ini setelah laporan tahunan dibuat dan dilakukan audit laporan keuangan. Apabila dengan segala kebijakan perusahaan tidak dapat menekan biaya, maka perusahaan perlu meningkatkan pendapatan dari penjualan barang dagang maupun dari pendapatan lainlain.

\section{DAFTAR PUSTAKA}

Baridwan, Zaki. 2004. Intermediate Accounting. Edisi 8. Yogyakarta: BPFE.

Darsono, Drs dan Ashari,S.E.,Akt. 2004. Pedoman Praktis Memahami Laporan Keuangan. Yogyakarta:Penerbit Andi.

Rudianto. 2012. Pengantar Akuntansi : Konsep \& Teknik Penyusunan Laporan Keuangan (Adaptasi IFRS). Jakarta: Erlangga.

Subramanyam, K.R dan John J.Wild. 2010. Analisis Laporan Keuangan. Buku1. Edisi 10. Jakarta: Salemba Empat.

Subramanyam, K.R dan John J.Wild. 2010. Analisis Laporan Keuangan. Buku2. Edisi 10. Jakarta: Salemba Empat.

Sugiyono. 1994. Metode Penelitian Administrasi. Bandung: Alfabeta.

Yusup, Al Haryono. 2011. Dasar-Dasar Akuntansi Jilid 2. Edisi 7. Yogyakarta: STIE YKPN. 